\title{
Derleme
}

\section{İnternete Pesimist Bir Bakış Açışı Olarak Makro ve Mikro Kapatılma}

\author{
Ahmet Faruk Çeçen (Dr. Öğr. Üyesi) \\ Ondokuz Mayıs Üniversitesi İletişim Fakültesi \\ ahmetfarukcecen1@gmail.com \\ Başvuru Tarihi: 12.10.2020 \\ Yayına Kabul Tarihi: 15.01.2021 \\ Yayınlanma Tarihi: 29.01.2021 \\ https://doi.org/10.17680/erciyesiletisim.809087
}

\section{Öz}

İnternete yönelik literatürde yer alan özgürlük-baskı ikilemine baskı tarafından bakan bu çalışma, benzer çalışmaların internet özgürlügünü genellikle baskıcı hükümetlerin kısıtlaması üzerinden algılamasını sorunsallaştırmaktadır. İnternet özgürlügünün iki boyutta tartışılması gerektiğini ileri süren çalışmaya göre makro doğrudan uygulanan bir kapatılmayken mikro dolaylı, bireyin kendisine uyguladığı bir kapatılmadır. Çalışmanın sorunsalı, baskı tarafındaki yaklaşımların makro düzeydeki yapılara olan vurgusunun aşırı düzeyde olduğu ve makro düzeydeki kapatılmaların aşılabildiği ve yine bu makro yapıların ve bireylerin kendilerinin de katkılarıyla yaratılan internet ortamının mikro düzeyde özgürlüğü talep etmeyen bir tip oluşmasına katkı sağladı̆̆ıdır. Yönetim açısından tahakküm yerine rızayla oluşan konsensüs evla olduğu gibi makro düzeyde interneti kapatmak yerine mikro düzeyde bireyleri özgürlüğü talep etmeyecek bir konuma indirgemek de daha tercih edilebilirdir. Buradaki özne büyük kapatılma içinde yaşayan, interneti de bir kültür endüstrisi aracı olarak kullanan, kendisi bu endüstrinin ürünlerini tükettiği gibi kendisinin de tüketilmesine izin veren ve internet özgürlüğüne aldığ hazdan daha az değer veren bir durumdadır. Hükümetler ne kadar baskıcı olursa olsun internetin doğası gereği özgürlüğe daha açık olan yapısı da düşünüldügünde, bu durum bireylerin internet ve teknoloji ile olan ilişkisinin daha fazla sorgulanması gerekliliğini ortaya koyar. $\mathrm{Bu}$ tespit literatürde internet özgürlüğünün genellikle tartışıldığı alan olan hükümet baskısından ziyade, kullanıcıların eylemlilikleri üzerinden tartışılmasının önemini vurgular.

Anahtar Kelimeler: Büyük Kapatılma, Disiplinci İktidar, İnternet Özgürlügü, Makro Kapatılma, Mikro Kapatılma. 


\title{
Macro and Micro Confinement as a Pessimistic Perspective towards Internet
}

\author{
Ahmet Faruk Çeçen (Asst. Prof. Dr.) \\ iD Ondokuz Mayıs University Faculty of Communication \\ ahmetfarukcecen1@gmail.com
}

Date Received: 12.10 .2020

Date Accepted: 15.01.2021

Date Published: 29.01.2021

https://doi.org/10.17680/erciyesiletisim. 809087

\begin{abstract}
An optimist vs. pessimist debate on the internet has been a long-standing one. Albeit taking side with the pessimistic side of the literature, the perception of internet freedom generally over the restriction of oppressive governments by this side appears to be problematic for this study. Restriction of internet freedom could be happening in macro and micro levels, emphasizing direct and indirect confinement respectively. The hypothesis of the study would be the pessimistic approaches of internet freedom overemphasize the effects of macro structures as internet censorship can be bypassed thanks to the internet's decentralized technical structure. However, the environment created and tools provided by these macro structures and the individuals per se have been contributing a specific subject type who is unwilling to demand freedom. Contrary to macro confinement, micro confinement is carried out by the individuals to themselves or they would have acted differently, like figuring out the way to get out of the system created by macro structures. Therefore, it should be emphasized that internet freedom must be heavily discussed not in terms of governmental repression but individuals' own actions.
\end{abstract}

Keywords: Disciplinary Power, Great Confinement, Internet Freedom, Macro Confinement, Micro Confinement. 


\section{Giriş}

Foucault'ya göre 17. yüzyılda Avrupa'da önemli bir değişiklik olmuştur. 1656 yılında Paris'te 'genel hastane' adı altında bir yapı kurulmuş ve yaklaşık altı bin Parisli (Paris nüfusunun yüzde 2'si) burada gözetim altına alınmıștır. Bu kurumun tıbbi bir amacı olmadığını ileri süren Foucault, bu yapının Avrupa'da diğer ülkelere sirayet ettiğini, deliler, hastalar, eşcinseller, yaşlı ve fakirler ve bedensel kaynaklı bir özür ya da başka nedenlerle çalışamayan yersiz yurtsuz insanlardan oluştuğunu ileri sürmüştür (Keskin, 2011, s. 13). Yukarıda ele alınan tipolojinin ortak noktası aylaklıklarıdır (Porter, 1990, s. 47).

Foucault (2011, s. 104-106) genel olarak toplum kurallarına uymadıkları için istenmeyen kişilerin farklı toplumlarda farklı uygulamalara (sürgün, katletme) maruz kaldığını ileri sürmüştür. Ortaçağ'da Avrupa'da ortaya çıkan kapatma pratiği yani mahkemeden geçmeden doğrudan hapsedilmek Avrupa'ya ve yaşanan döneme özgüydü. Bu tip bir kapatılmaya neden ihtiyaç duyulduğuna dair Foucault'nun cevabı siyasi ve ekonomik nedenlerdir. Daha spesifik olarak İspanyol ekonomisindeki krizin tüm Avrupa'ya etkisi onun için önem arz eder. Kapatılma böyle bir durumda iki açıdan avantajlıdır. Birincisi bu işsiz ve aylak kesim ekonomik krizde bașkaldıramaz ve ikincisi krizden sonra ucuz ve kolay denetlenebilir bir iş gücü oluşturulabilir (Keskin, 2011). Bu kapatılma mantığ öncelikle hapishane ve akıl hastanesi gibi kapatılanların farklı fiziksel mekânlara kapatıldığı farklı kurumları doğurmuş ve somut bir işlev görmüş, sonrasında kapitalizm ile tüm toplumu kontrol edebilmenin sembolik bir aracı haline dönüşmüştür.

Marksistler tarafından Marksist düşünceye yönelik bakış açısı nedeniyle, çokça eleştirilen Foucault bu spesifik örnek için yaptığı analizde neredeyse bir Marksist kadar ekonomik determinist $^{1}$ bir duruş sergileyerek kapatılmayı ortaya koyan koşulları ekonomik etkilerle açıklar. Yukarıda belirtildiği gibi kapatılmanın ilk nedeni ekonomik krizlere karşı bir önlemdir. Sonrasında ortaya çıkan hapishanelerin nedeni ise kapitalizmin el emeği ve işsizlik gibi yeni sorunlarla karşı karşıya gelmesi ve eski isyanları bastırma yöntemi olan insanları katletme ve mülklerini ortadan kaldırmanın ekonomik olarak elverişsiz olmasıdır. Yani yine ekonomik gerekçelerle hapishaneler ortaya çıkmıştır. Foucault'yu ekonomik determinist olarak adlandırılmaktan kurtaracak analizi ise kapatılma kurumlarının ekonomik olarak işlevsiz ve verimsiz olduğunun anlaşılmasına rağmen bu yapılarda ısrar edildiğini ileri sürmesidir. Foucault'ya göre bu ısrarın nedeni, kapatma pratiğinin güçlü bir toplumsal denetim sağlamak ve kapitalizmin ihtiyaç duyduğu iş gücünü üretmek için görünürden çok daha ince ve etkili bir işlev yerine getirmesidir. Bununla beraber eski kapatılma tekniklerinin (hapishane, ıslahevi, akıl hastanesi ve askeri fabrikalar) aşırı pahalı ve etkisiz bulunması ve insan bedeninin doğrudan ekonomik ve siyasi müdahalenin nesnesi haline gelmesi nedeniyle yeni bir teknik ortaya çıkmıştır. Keskin (2011) bu yeni tekniği şu şekilde açıklar: “Bu teknik kapitalist üretim biçiminin gerektirdiği disiplin ve uysallığın insanlar tarafından benimsenip içselleștirilmesine ve gönüllü olarak uygulanmasına dayanır. Böylece on sekizinci yüzyıl sonunda Avrupa'da Foucault'nun 'disiplinci iktidar' adını verdiği yepyeni bir iktidar türü çıkmıștır. Bu iktidarın uysallaştırma ve verimli hale getirme yöntemi ise şiddet ve bedensel zorlamaya değil, insanlara belli öznellik biçimleri dayatılmasına dayanır." Tüm bu anlatılanları basit bir şekilde ifade etmek gerekirse, Foucaultcu anlamda iki tür kapatılmanın olduğu ileri sürülebilir; fiziki ve ruhsal eş deyişle insanın kendini kapatması, çünkü Foucault büyük kapatılmanın insan ruhunda olduğunu söyler. Dijital ortamdaki kapatılmanın peşine düşen bu makalede fiziki kapatılma makro, ruhsal kapatılma ise mikro kapatılma olarak 
adlandırılacaktır. Bu iki kapatılma tipi de internet özgürlügüne yönelik pesimist bir bakış açısına işaret eder. Bununla beraber bu çalışma literatürdeki genel ağırlığın aksine internet özgürlüğ̈̈nü genellikle baskıcı hükümetlerin kısıtlaması üzerinden algılanması sorunsallaştırmaktadır. Çalışmanın sorunsalı adı geçen ikilemde baskı tarafındaki yaklaşımların makro düzeydeki yapılara olan vurgusunun aşırı düzeyde olduğu ve makro düzeydeki kapatılmaların aşılabildiği ve yine bu makro yapıların ve bireylerin kendilerinin de katkılarıyla yaratılan internet ortamının mikro düzeyde özgürlüğü talep etmeyen bir tip oluşmasına katkı sağladığıdır. Bu noktada çalışma, hükümet ve şirket gibi makro yapıların biçimlendirmek istediği özne kalıbına uyum sağlayan günümüz internet kullanıcısına dair bir tipoloji oluşturmayı amaçlanmaktadır. Buna ek olarak çalışmada makro ve mikro kapatılma türlerinin tanıtılmasını ve bu türlere yönelik daha derinlikli araştırmalara bir kapı açılması da amaçlanmıştır. Bu makale ileride bu tez ve kavramsallaştırmaları nitel ve nicel verilerle destekleyecek çalışmalar adına bir temel oluşturmayı amaçlamaktadır. Bu açıdan bu çalışma teorik bir çerçeve oluşturma çabasıyla sınırlandırılmıștır.

\section{Bir Açma ve Kapatılma Aracı Olarak İnternet}

Merkezi olmayan teknik işleyişi nedeniyle özgürleștirici bir yapısı olan internete atfedilen bu özgürleștirici yeti, literatürde ciddi bir șekilde yer tutmaktadır. Bu yetiye değer verilmesinin en önemli nedenlerinden biri de WikiLeaks gibi yapıların hükümet ve şirketlerin, kamunun çıkarlarına karşı olan eylemlerini belgeleyen dokümanları sızdırabilmesi ve bu yapıların internetin merkezsiz yapısından güç alarak gelen saldırılara karşın bu sızdırmayı sürdürebilmesidir. Bu durum 28 Kasım 2010 gecesi Wikileaks, ABD Dışişleri Bakanlığı'na ait belgeleri yayınlamaya başladığında tam olarak böyle olmuştu. ABD Julian Assange'ın peşine düştü, sitenin sunucularını çökertmeye çalıştı, Amazon gibi yer sağlayıcı firmalara hizmeti durdurmaları için, mali kaynakları kesmek için Paypal ve Visa gibi finans şirketlerine baskı uyguladı, dezenformasyon makineleri çalıştırdı. Ancak aksine Wikileaks ve Assange'ın popülaritesi arttı, sızıntılar farklı sunucularda belirdi, ABD baskısına boyun eğen şirketler anonim hacker kabileleri tarafından saldırıya uğradı ve WikiLeaks benzeri projelerin sayısı artmaya başladı (Ertem \& Uçkan, 2011)

WikiLeaks'in Amerikan hükümetinin halkın çıkarlarına karşı olduğunu ileri sürdüğü yazışmalarını karşıt kamuoyu oluşturacak şekilde sızdırması, pek çok düşünüre göre internetle beraber artık kamunun ortak çıkarının çok daha kolay savunulabileceğine ve kamu çıkarına karşı girişilen eylemlerin gizlenemeyeceğine dair bir etki oluşturdu. WikiLeaks'in biz hükümetleri açarız sloganı ile hareket etmesi, çalışmada ele alınan kapatılma kavramının bir anlamda zıddı olarak konumlandırılmalıdır. Bu gizli olanı 'açma' girişimini yapan Assange ve arkadaşları (2013) bu eylemin gerçekleşmesini sağlayan interneti, iktidarın 'gerçekliği tanımlama yetisini kendi ellerinden alan bir hastalık' olarak gördüğünü söyler. Assange'ın hastalık metaforu ile Foucault'nun kapatılanlara dair ortaya koyduğu tipolojiye yönelik yaratılan söylem düzeni benzerlik gösterir. Kapatılmanın içselleștirilmesi için kapatılma koşullarının genelleşmesi ya da genele kabul ettirilmesi, en temelinde bu konuda rıza üretilmesi gerekmektedir. Bu bir anlamda kapatılanların kapatılmasının meşrulaştırılmasıdır. Fiziki kapatılma açısından 17. yüzyıl Fransasında deliler, hastalar, fakirler, eşcinseller ya da çalışmak istemeyenlerin marjinal olarak gösterilip kapatılmasının halka benimsetilmesi ile Assange ve ekibinin terörist, hain ve en temelinde marjinal gibi gösterilip WikiLeaks'e internet üzerinden ulaşılamamasının benzerlik gösterdiği ileri sürülebilir.

İnterneti odağına alan bu çalışmada internete atfedilen gücün internet öncesi dönemde televizyona atfedilmesine dikkat çekilmesi bir zarurettir. Bu minvalde Postman'ın (1985) 
televizyona yönelik meta-ortam bakış açısı günümüzde internete karşılık gelmektedir. Bunun nedeni bir şeyi bilme yolumuzun artık internet üzerinden geçmesidir. Postman'ın televizyona yönelik eleştirisinin farklı bir versiyonunu internete uygulayan Carr (2020) da Postman gibi teknolojik gelişmelerin zihin ve bilgiye bakış açısını nasıl şekillendiğini anlamaya çalışır. Ona göre insanlar artık ciddi bir odaklanma sorunu yaşamakta, çok işi bir arada yapmak isterken dikkat dağınıklığından ötürü belki de hiçbirini tam olarak yapamamaktadır ve bunun sonucu da zekayla ciddi bağlantısı olan uzun süreli belleği körelmesidir. Eş deyişle Google ya da internet bizi aptallaştırmaktadır. Herkesin kilitlendiği ekranlardan başını kaldırırsa sürekli dikkatimizi talep eden dijital bir hapishanede olduğumuzu görebileceğini söyleyen Hassan (2019) bu bağımlılı̆̆ın sadece saatlerimizi değil bizi biz yapan şeyleri de götürdüğünü ileri sürer. Tüm bu yazarların ortak düşüncesi internetin ve dijital cihazların bizi ve beynimizi dönüşmesi kapasitenin büyüklügüudür. Eş deyişle insanın bu cihazlar sayesinde değişim kapasitesi toplumları yönlendirmek isteyenler için bulunmaz bir nimettir.

Cebri kontrol ve konsensüs kontrolünü ele aldıkları 1984 ve Cesur Yeni Dünya kitaplarında Orwell kitapların yasaklanacak olmasından, Huxley onları okuyacak kimsenin olmamasından, Orwell bilgiden yoksun edecek kişilerden, Huxley bize gereken fazlasını verip pasif ve bencil hale düşürülmemizden ve son olarak Orwell doğrunun saklanmasından, Huxley eğlence sayesinde bilginin ilgisizlik dehlizinde boğulmamızdan korkuyordu (Postman, 1985) - (McMillen, 2009). Bu araștırmada bir anlamda internetle beraber bu yazarlardan hangisinin görüşlerinin daha geçerli olduğu tartışılmaya çalışılacaktır.

Foucault'nun kapatılma kavramının evrimine bakıldığında fizikiden ruhaniye belirli bir tipolojiden tüm topluma doğru bir seyir izlediği görülebilir. İnternette gerçekleştirilen kapatılmanın da benzer bir seyir izlediği iddiası makro (fiziksel) ve mikro (şahsi ve ruhani) kapatılma üzerinden açıklanmaya gayret edilecektir. Bunun öncesinde iki kapatma türüne de etki eden iki boyut (gözetim ve şirket ve bireylerin özgürlük baskı ikilemindeki tutu$\mathrm{mu}$ ) incelenecektir.

\section{Kapatmak için Gözetlemek}

Gözetim yukarıda belirtildiği gibi her iki kapatılma türü adına da etkili bir unsurdur. İnternet özgürlüğünü kısıtlayabilmek adına öznelerin hareketlerinin izlenmesi ve o hareketlere karşı hamlelerin yapılabilmesi gerekmektedir. Aynı zamanda bu her zaman izlenebilmenin yarattığı süper panoptikon hali de mikro kapatılmalara da neden olabilir. $\mathrm{Bu}$ durum bir anlamda insanların birbiriyle irtibat kurduğu her ânı ya da bıraktığı her dijital izi gözetleyen, izleyen bir güce işaret eder. Şifrepunk’ın yazarlarının arasındaki bir diyalogda bu konu şöyle işlenir:

"Yalnızca Amerikalılar, İngilizler ve Rusların, bir de İsviçre ve Fransa gibi birkaç devletin kitlesel gözetim uyguladığı döneme klyasla bugün gözetleme çok daha bariz bir hal almış durumda. Bugün kitlesel gözetlemenin ticarileşmesi sayesinde herkes, neredeyse bütün devletler bunu uygulayabiliyor (Assange, Appelbaum, Müller-Maguhn, \& Zimmermann, 2013)."

Morozov (2011) insanların sosyal medyada kurdukları iletişimlerin gizli bir şekilde bilinmeyen üçüncü șahıslara aktarıldığını ve hatta onların bilgisayarı ile Google gibi firmalara saldırıldığını ileri sürer. Hem de bu durumla karşılaşan bilinçsiz kullanıcılar değil internet aktivistleridir. Eş deyişle gözetim sadece internet bilgisi sınırlı olan sıradan kişileri değil üst düzey bilgiye sahip olan kişileri de tehdit etmektedir.

Gözetimin tekil șekilde muhalif isimlere yapılmasının dışında büyük veri mantığıyla kitlelerin genel olarak profillerinin çıkartılıp onlara göre eylem planlarının oluşturulması 
ise dijital analitik ile mümkün olmaktadır. Facebook, Google ve Twitter gibi teknoloji devleri müşterilerine kitlelerin demografik bilgilerinden, beğenilerine ve ilgi alanlarına kadar geniş yelpazede bilgiler sağlar. Bu durum da doğru kitleye doğru propagandayı yapıp sonuç almayı beraberinde getirir.

\section{Şirket ve Bireylerin Özgürlük Baskı İkilemindeki Tutumu}

Şirketlerin ve bireylerin özgürlük baskı ikilemindeki bakış açıları çok önemlidir. Çünkü onların pozisyonları kullanıcılarının verilerinin nasıl işleneceği ya da kimler tarafından kullanılabileceğinin anahtarıdır. Şirketlerin elinde bulunan verilerin pazarlaması ve devlete sağlaması tehlikeleri mevcuttur. Gözetleme ticarileşmiş ve özel sektör eliyle bedava kullanıldığı düşünülen uygulamalar sayesinde devasa oranda veri toplanabilmektedir. Buna ek olarak yasakçı kanunlar ve devletin şirketler üzerindeki baskısı da şirketleri kullanıcılarının verilerinin güvenliği konusunda kullanıcı aleyhine bir tutuma doğru itebilir. Örneğin WikiLeaks ifşalarından sonra bu grubun üyeleri kendilerinin anayasa dışı olduğunu iddia ettikleri keyfi arama ve özel eşyaya el koyma gibi uygulamalara maruz kalmışlardır. WikiLeaks ile ilintili kişilerin özel verileri talep edilmiştir. Kendisinden veri talep edilen Twitter'ın bu kişilere durumu haber vermesi bile yasaktı. Twitter bu konuda bir hukuk mücadelesi verdi ve bu hakkı elde ederek ilgili kişilere haber verebildi.

Google'ın hükümetle olan bağlantılarının onu yukarıdaki şirketlerden farklı bir konuma sürüklediği ileri sürülebilir. Örneğin Amerikan hükümetinde dış işlerinde görev yapan Jared Cohen gibi isimlerin Google'da çalışması dikkat çekicidir. Amerikan Dışişleri Bakanlığı'nda çalışırken Cohen 2009 yılındaki İran ayaklanmasında Twitter'ın planlı bakımını ertelemesi konusunda e-mail atan kişi olarak da bilinmektedir. Cohen'in aynı zamanda Google için çok önemli bir isim olan ve Amerikan hükümetiyle ilişkisi dikkat çeken Eric Schmidt ile olan ilişkisi dikkat çekicidir. 2016 yilında kurulan ve Amerikan Savunma Bakanlığı'na danışmanlık yapan bir anlamda teknoloji devi şirketlerle Amerikan Ordusu arasındaki bağı kuran Savunma İnovasyon Kurulu'nda ${ }^{2}$ başkan ve teknik danışman pozisyonunda olan eski Google CEO'su ve Google'ında içinde bulunduğu çatı kuruluş olan Alphabet'in eski yönetim kurulu başkanı olan Schmidt, 2001 yılından beri Google için çok önemli görevlerde bulunmuştur. Bu ikilinin yazmak üzere oldukları bir kitap için 2011 yılında Jullian Assange'la buluşmaları, o dönem Google'ın CEO’su olan Schmidt'in internete bakış açısını gösterir. Schmidt'e göre özgürleşme Amerikan dış politikasının hedefleriyle doğru orantılıdır ve Batılı olmayan ülkeleri Batılı şirketlerle bağlantılı hale getirmekle gerçekleştirilebilir (Assange, 2014) Bu durum şirketlerin kendi kullanıcıları yerine devletlere hizmet ettiğine dair başka bir etik problemi de gündeme getirir. Şirketlerin kendi kullanıcılarından ziyade devletlere ve kâr amacıyla diğer şirketlere hizmet etmesi gözetim gibi önemli bir unsur olup hem makro hem de mikro kapatılmayı etkiler.

Google örneği üzerinden devam edersek, Google kullanan biri hakkında nereye gittiği (Maps), kimlerle irtibatta olduğu (Gmail vb.) ve arama motoru sayesinde hayata bakış açısından cinsel yönelimine kadar her şey bilinebilir. Google'ın Amerikan istihbaratına tüm verilerine ulaşım izni verdiği söyleniyor. Bu durum Google'ın mahkeme kararı yani yasal bir süreç bile olmaksızın kişisel bilgileri hükümet yetkilileri ile paylaştığı anlamına gelir. Benzer şekilde Facebook'un karıștığı Cambrigde Analytica skandalı Google'ın yaptıklarına benzer bir tabloyu karşımıza çıkartır.

Bu noktada durumun kompleks yapısı da göz önünde bulundurulmalıdır. Örneğin Facebook ve Twitter çalışmanın yapıldığı sürelerde Wikileaks'in hesaplarını gelen baskılara 
rağmen kapatmamıştı. Senato sorgusunda devlet dışı düşman istihbarat örgütü olarak tanımlanan Wikileaks ve kurucusu Julian Assange'ın hesaplarının neden hala açık olduğu konusunda Facebook'un baş operasyon direktörü Sheryl Sandberg şunları söylemiştir: "Şirketimizin sansüre karşı aldı̆̆ı kararları savunmadan önce platformumuzdaki herhangi bir aktör ya da sayfanın eylemlerini savunmayacağım gibi WikiLeaks'i de savunmayacağım. WikiLeaks'in paylaşımları kamusal boyutta olageldi. Diğer medyalarda bu paylaşımlar mevcut durumdadır. Bu özelliğinden dolayı bizim hizmet şartlarımızı ihlal etmiyor ve sitemize uyumlu durumda." Sanberg'de sonra söz alan Twitter'ın CEO'su Jack Dorsey ise şunları ilave etti: "Biz de hizmet şartlarımıza yönelik herhangi bir ihlal unsuruyla karşılaşmadık. Biz her zaman olduğunu gibi hizmet şartlarımıza yönelik ihlalleri işaret edecek hukuki yaptırım önerisine açı̆̆ız (Nelson, 2018)."

Şirketlerin sadece kullanıcılarının bilgilerini üçüncü taraflarla paylaşmaları değil aynı zamanda nasıl bir mimari ve algoritmik yapıyla hizmet verdikleri de özgürlügü yakından ilgilendirir. Sosyal medya şirketlerinin kâr mantığıyla sürekli kişilerin hoşuna gidecek şeyleri onlara göstermesi ve farklı görüştekilerle ortak bir kamuoyu yaratılmasına izin vermemesi internetin dolaylı yoldan bir baskı aracına dönüşmesine neden olabilir.

\section{Makro Kapatılma}

$\mathrm{Bu}$ çalışmada mikro kapatılmada detaylı olarak açıklanacak olan iktidar kavramına burada kısaca değinmek gerekirse, bu kavram ile bilinen siyasi iktidarın anlaşılmaması gerektiği ve kavramın içinde devlet, lobiler, uluslararası kuruluşlar ve şirketleri içerecek şekilde amorf bir yapıda olduğu söylenebilir. Bu açıdan bakıldığında makro kapatılma bu amorf yapılar tarafından fiziki araçlarla uygulanan bir yöntem olarak anlaşılmalıyken, mikro kapatılma bir durum ya da bu durumu içselleştirme biçimi olarak ele alınmalıdır. Makro kapatılma Foucaultcu anlamda işin şiddet (fiziki ve hukuki olabilir) ve bedensel zorlama kısmını içerir. Eş deyişle iktidarın özne ve öznenin bilgiye ulaşmassını sağlayan araçlar ve kişiler üzerindeki fiziksel bir eylemlilik biçimidir. Bu kapatılmanın en temel algılanışı iki şekilde gerçekleştirilebilir. Birincisi internete tüm vatandaşların erişimini engellemek, dolayısıyla kapamaktır ki bu oldukça otoriter ülkelerde görülen bir kapatılma biçimidir. Çin "Büyük Güvenlik Duvarı" bu konuda en can alıcı örneklerdendir. Rusya'nın da Çin'in izinden gittiğine dair iddialar yakın zamanda gündeme gelmiști (Shervin, 2019). Makronun altındaki ikinci tür kapatılma internette vatandaşlara içerik sağlayan ve hükümetleri açan WikiLeaks gibi kuruluşları baskı altına alma amaçlı olarak yapılan eylemlerdir. Bu iki temel kapatılmanın dışında ek makro kapatılma biçimleri de mevcuttur.

Daha geniş bir şekilde ifade etmek gerekirse, makro kapatılma direkt olarak yasakla, mahkeme kararıyla ya da devletin (bazen de özel sektör taşeron olarak kullanılabilir) fiziki olarak interneti engelleme çabalarıyla ve kendilerine aykırı yayın yapanların gözünü korkutarak veya onları fiziki olarak engelleyerek internetteki özgürlük ortamına yönelik somut engellemeleri olarak anlaşılmalıdır. Bu bir anlamda tepeden aşağıya yönelik bir kapamadır. Bu kapatılmanın araçları olarak denetim (gözetim ile beraber uygulanır), yasakçı kanunlar ve fiziki zorbalıklar gibi unsurlar sayılabilir.

\section{Makro Kapatılma Çeşitleri}

Görüldüğü gibi kapatılmanın gerçekleşebilmesi için internetin ciddi bir gözetim ve denetim mekanizması haline getirilmesi gerekir. Günümüzde Google, ziyaret edilen siteler, Facebook ve hatta Whatsapp çerezler sayesinde kullanıcı hakkında bilgileri toplamakta ve interneti bir anlamda kontrol edilebilen bir şekle dönüștürmektedir. 
Artık kontrol edilebilen bu yapıda izlerini bırakan sıradan insanlar ve aktivistler çeşitli kapatılmalara maruz kalmaktadır. Bu mekanizma için küresel gözetlemeden, mali ve fiziki ablukaya, devletin özel şirketlerle olan sıkı bağlantısından mahkeme yoluyla özel şirketleri zorlamaya ve denetimi teknolojinin yani donanım ya da yazılımın içine koymaya kadar pek çok makro kapatılma çeşidi bulunmaktadır.

\section{Internete Fiziki Kapama}

İnternet sansürü olarak adlandırılabilecek bu durum internete yönelik toptan engelleme, belirli internet sitelerini engelleme ve içerik engelleme olarak kategorize edilebilir. Fiziki kapatılma açısından çocuk pornografisi gibi üzerinde herhangi bir tartışma bulunmayan kapatılma durumları olmakla beraber WikiLeaks örneğinde bu kapatılma biçimi kamuoyu çıkarı için hareket ettiği düşünülen yapıların kapatılması açısından eleştirilebilir bir hal alabilir. Althusserci anlamda devletin baskı aygitı olarak konumlandırılan mahkemeler, internet özgürlüğünün baltalanması açısından araçsallaştırılabilir. Ya da baskıcı kurumlar açma girişimi yapan siteler mahkeme kararı olmaksızın kapatılabilir. Bu durum bir öznenin hapse atılması kadar somuttur ve internetin ya da belirli sitelerin etki alanı içinde barındırılmaması ile açıklanabilir. Örneğin Çin'de devlet kontrolü ile uluslararası pek çok site devre dışı bırakılmaktadır (Warf, 2011). Öznenin tüm makro kapama biçiminde bir dahli yoktur. Ancak VPN gibi yöntemlerle kısmi olarak bu kapatılma biçimini aşabilir. Kişiler farklı IP adresleriyle internete bağlanarak ve bu IP adresleri onları farklı ülkelerde göstererek bulundukları ülkenin internet rejimini aşabilmektedir.

\section{Açımlamayı Gerçekleștirenlere Mali ve Fiziki Kapama}

Assange ve arkadaşlarına göre WikiLeaks'in mali kaynağını destekçi bağışları oluşturmaktadır. Wikileaks ifşalarından sonra pek çok kurum Wikileaks ile olan ilişkilerini durdurmuşlardır. Assange engellendiği için onun yerine bir konferansta konuşma yapan Jacob Applebaum'a bu konferanstan sonra baskı yapılmaya başlandı. (Assange, Appelbaum, Müller-Maguhn, \& Zimmermann, 2013). Bu durum açımlamayı yapanlar kadar bunları talep edenler için de geçerli olabilir. Örneğin mali abluka sadece Wikileaks aktivistlerine değil ayrıca destek olan kişilere de yansımıştır. Buna ek olarak Amerika'da WikiLeaks üzerinde "çalıntı belgeler" tartışması yaşanmış ve bu belgeleri bulundurmanın suç olduğu söylenmişti.

\section{Tarihi ve Arşivi Kapatmak Dolayısıyla Hafızayı Kapama}

Medeniyeti, özgürlüğü yok etmenin en kolay yolu belki de arşivleri, doğal olarak da insanın hafızasını yok etmektir. Dijital ortamda yayın yapan gazeteler matbu versiyonları gibi arşiv özelliği, eş deyişle tarihe not düşme özelliği taşımaktadır. Ancak bir matbu yayın bir kez çıktıktan sonra onu değiştirmek ya da yok etmek oldukça zor iken bu durum internet gazeteleri için geçerli değildir. Gazeteler iktidar ve elitlerle ilişkileri hasebiyle bu eylemi kolayca yapabilir Assange ve arkadaşları bu konuda şunları söyler:

İngiltere'de Guardian ve diğer belli başlı gazeteler kendi internet arşivlerinden birtakım haberleri gizlice, hiçbir ibare koymadan siliyorlar. Bu sayfalara gittiğiniz zaman karşınıza «sayfa bulunamadı» uyarısı geliyor (2013).

Bilgilerin yok edilmesi metaforik olan İskenderiye Kütüphanesi'nin yıkımına benzetilebilir. Tarihte bir yeri fetheden her medeniyet mimari, bilginin dağıtımı ve inanç sistemi gibi açılardan kendi gücünü hissettirme çabasındadır. İskenderiye Kütüphanesi gibi bilginin dağıtımını sağlayan yerler de bu güç savaşının bir parçası olarak bu durumdan etkilenmiştir. Bu tarihsel perspektiften günümüze gelindiğinde güç odaklarının internet üzerinde bilginin dağıtımı adına bir güç mücadelesine giriştikleri söylenebilir. Bazı siteler 
ve internetteki bilgilerin başına gelen de İskenderiye Kütüphanesi'nin başına gelene benzemektedir. Tarihin silinmesi ile ilgili Assange ve arkadaşları şunları ekler: "Tarihi yalnızca tahrif etmekle kalmıyorlar, tarih sanki hiç olmamış gibi yapıyorlar. Orwell'in ünlü bir sözü var, "Bugünün ipleri kimin elindeyse, geçmişi de o kontrol eder ve geçmişi kontrol eden her kimse, geleceğin dizginleri de ondadır." Batı'da tarih, tespiti mümkün olmayan bir biçimde siliniyor (2013)." İnternet siteleri ile sosyal medya platformları da benzer şekilde içerikleri hatta bu içerikleri sağlayan sayfa, grup ve kişilerin profillerini de kapatabilir. Buna ek olarak internet ortamındaki içeriklerin sürekli güncellenebilir bir halde olması onların sadece silinerek değil orijinalinden farklılaştırılarak da bir kapama içinde olunabileceğini gösterir. Öznenin bu kapatılma biçiminde de bir dahli yoktur. Sitelerin silinen versiyonlarının kaydedilmediyse orijinale ulaşması mümkün değildir. $\mathrm{Bu}$ orijinaller internette var olmaya devam etse bile orijinal kaynaktaki değiștirilmiş versiyonları her zaman daha otantik bir görüntü sergiler.

\section{Denetimi (Kapatılması) İçinde Teknolojiler}

Aaron Swartz karasal ve kablolu yayının olduğu dönemde kamuya seslenmenin sadece bir zümrenin elinde olduğunu söyler. Ancak şimdi internet sayesinde bu durum değişmiş, herkesin kendine ait bir kanalı ve kendini ifade etme şansı olmuştur. Aaron'a göre artık kimin hava dalgalarına erişimi olduğu değil, insanları bulma yöntemlerine kimin hükmettiği yeni problemdir. $\mathrm{Bu}$ durumda güç artık Google gibi sitelerde merkezileșmektedir. Bu tip yapılar internette nereye gitmek isteyeceğini insanlara söyleyen eşik bekçilerine dönüşmüşlerdir. Aynı zamanda bizim haber ve enformasyon kaynaklarımızı sağlayanlar da onların gözetiminden geçer. Bu durum sadece yetkisi olanların konuşması ve yetkisi olmayanların sesinin duyulmaması anlamını tașır. Eș deyişle sorun artık kimin konuşabildiği değil kimin sesinin duyulduğudur (King, 2006). Amerika gibi ülkelerde Google üzerinden bir tartışma yaşanırken Çin gibi ülkelerde ise farklı şekilde kapatılmalar yaşanmaktadır. Paltemaa ve arkadaşları (2020) Pariser'ın “her kullanıcı için farklı enformasyon evreni" düşüncesi ve Filtre Balonu kavramı üzerinden Google, Facebook ve Twitter gibi Amerikalı internet şirketlerinin meta enformasyon kontrolü açısından tartışıldıklarını ileri sürer. Yazarlar liberal bağlama benzer şekilde Çin'deki sansürün o bağlamda bir enformasyon balonu yarattığı ve bu balonun Komünist Parti'nin çıkarlarına ters düşecek resim ve enformasyonu engellediğini ortaya koyarlar. Bu noktada ister Google İster Badui olsun, kullanıcıya sunulan bu araçlar hâlihazırda bir denetim ve kapatılma içerisindedir.

Bununla beraber bilgiye ulaşma araçlarımızdan biri olan arama motoru Google, yazılım donanım olarak karşı karşıya olduğumuz teknoloji ile olan ilişkimizde, büyük oranda yazılım açısından bir yer işgal ediyor (ya da arama motoru Badui). Google'a ulaşmamızı sağlayan donanımlar, örneğin laptoplar ve mobil cihazlara bakacak olursak, bu cihazların Mcluhancı anlamda bizim giderek bir uzantımız haline dönüşmekle beraber onları kavrama açısından bizden bir hayli uzaklaştığını söylemek mümkündür. Assange ve arkadaşlarına (2013) göre şirketler artık ya karmaşık ürünler üretiyorlar veya onların anlaşılmasını yasal olarak güçleştiriyorlar. Örneğin eskiden mobil telefonlar üzerinde kullanıcı olarak hâkimiyetimiz daha fazlaydı. Artık telefonların bataryalarını bile değiştirmemize izin verilmiyor. İster telefon ister bilgisayar olsun şirketler artık bu cihazları donanımsal olarak artık anlamamamızı ve bir bütün olarak bu cihazları kullanmamızı istiyorlar. Eş deyişle ürüne sadece onların istediği kullanım açısından sahibiz. İçindeki teknolojinin ve parçaların bizim sahipliğimizde olması istenmiyor. Assange ve arkadaşları (2013) bu durumu bir teknolojik ürünün asıl yapım amacına hizmet edip etmediği veya ne 
derecede hizmet ettiği üzerinden değerlendirir. Üretilen bu karmaşık ürünler, satın alan bizlere hizmet etmekten ziyade bizi araçsallaştıracak şekilde bizi sürekli bir tüketiciye dönüştürüyor. Donanımsal açıdan bu ürünler üzerindeki kişiselleştirme çabamız koruyucu kılıflardan öteye geçemiyor. Bu noktada bu durumun toplum için tehlikeli bir şey olarak düşünülmesi gerektiği ortadadır. Zira şirketlerin her zaman iyi niyetli olduğunu düşünmek oldukça safça olabilir. Örneğin Google Android'in sahibi olduğundan her türlü yazılımı yüklemeyi kendine hak olarak görür. Buna ek olarak Google yaptığı çalışmalarla artık Android 11'de apk ile dışarıdan dosya yüklemeyi engellemeye çalışmaktadır (Kalelioğlu, 2020). Hatta ön yükleme durumu Rusya örneğinde olduğu gibi devletlerin telefonların, laptopların ve akıllı televizyonlar kullanıcıya ulaşmadan içlerine yerleştirdikleri yazılımlar sayesinde doruk noktasına ulaşmıştır (Lakshmanan, 2019). Görüldüğü gibi günümüzde denetimi giderek teknolojinin içine yerleştiriyoruz. Donanımsal olarak hâkimiyetimizin olmadığı ve önceden yazılımlar yüklenen araçları yine Google, Netflix, Badui, Twitter ve Facebook gibi şirketlerin kısıtlılıkları aracılığıyla kullanıyoruz. Denetim artık teknolojinin dâhili bir parçası.

\section{Mikro Kapatılma}

Makro kapatılma kısmında, bu çalışmada iktidar kavramı ile ne kastedildiği kısaca aktarılmaya çalışılmıştı. Bu kısımda daha detaylı aktarmak gerekirse, Foucault'nun (1980) kılcal iktidar (capillary power) kavramına başvurmak faydalı olacaktır. İktidar Batı'da artık stabil olmayan, bireylerin her zerresinde kendini hissettiren, onların eylemlerini, davranışlarını, söylemlerini, öğrenme süreçlerini ve günlük hayatlarını belirleyen bir konuma eş deyişle onları her neyseler o yapan şeye dönüşmüştür. Bu perspektiften yol çıkarak çalışmada iktidar salt siyasi bir yapı olarak ele alınmamıştır. Bu şekilde anlaşılan iktidarın tek başına ya da lokomotif görevi görerek özneyi gözetleme ve dönüştürme tekeli bulunmamaktadır. Devlet denen siyasi yapı gözetleyen ve dönüștüren 'şeyin' bir parçasıdır. Bu noktada önemli olan neo-liberal yapının uluslararası düzeyde devamı adına uluslararası kurumlar, devletler ve şirketlere düșen görevlerdir. WikiLeaks nasıl hükümetlerin işleyişi adına bir tehlike arz etmişse çok daha basit bir olay olarak görülebilecek olan Aaron Swartz'ın JSTOR'un veri tabanından elde ettiği akademik yayınları halka açık hale getirmesi de sistem açısından ciddi bir tehlike olarak görüldü. Buradaki iktidar kavramı somut ya da komplo teorilerinde yer alacak şekilde belli bir zümre açısından algılanmamalıdır. Bununla beraber burada iktidar olarak tanımlanan amorf yapı makro açıdan şiddet ve bedensel zorlamaya dayanırken, mikro açıdansa insanlara belli öznellik biçimleri dayatılmasına dayanır. Eş deyişle makro doğrudan bir kapatılma iken mikro dolaylı olan, bireyin kendisine uyguladığı bir kapatılma biçimidir.

Ancak bireyin kendisine uyguladığı kapatılma biçimi bir tercih gibi görülse de en temelinde makro yapıların birey üzerinde uyguladığı toplumsal ve psikolojik baskı ve teknolojik yönlendirme sonucu ortaya çıkar. Yapısalcı bir açıdan bakacak olursak, kurgulanan sistemlerin birey psikolojisine etkisi ve onun eylemliliğini yönlendirmesini ortaya koyar. Sistemleri geliştirenler kişilerin dikkatini maksimize edebilmek adına algoritmalarını ortaya koyarlar ve dikkat ekonomisi adında bir kavram ortaya çıkar. Ama burada dikkat edilmesi gereken nokta bu sistemler her ne kadar kuşatıcı olsa da mutlak bir dayatma değillerdir.

Mikro kapatılma, makro kapatılmadan farklı olarak bireyin kendi eylemlilik haliyle bu kapatılmayı kendisinin gerçekleştirmesini ifade eder. İnternetin özgürleştirici işlevini bireylerin hiçbir şekilde içselleştirmemesi ya da özgürleştirici bir etkinlik içinde yanılsaması içinde olmalarıdır. Bu kapatılma türü Foucaultcu (2011) bir anlamda 
insanların ruhlarındadır. Aslında eylemlilikleri üzerinde doğrudan bir ceberut iktidar gücü, direkt bir yasaklama yoktur. Ancak kapitalist disiplinci iktidarın onları özneleştirdiği konumda eylemliliklerini var ederler, o pratikleri uygularlar. Makro doğrudan bir kapatılma iken mikro dolaylı olan, bireyin kendisine uyguladığı bir kapatılma biçimidir.

Günümüzde yeni medya araçları vasıtasıyla kitle iletişim araçlarında olduğundan daha bile fazla şekilde bireye kullanım açısından otonomi atfedildiği düşünüldüğünde Foucault'nun "disiplinci iktidar" ve "kapatılma" kavramları ve Frankfurt okulunun "kültür endüstrisi" kavramından yararlanan mikro kapatılma kavramı önem kazanmaktadır. Bu kavramı daha iyi anlamak çeşitlerine göz atmakta fayda var.

\section{Gözetim Korkusu ve Gözetimi Íçselleştirme}

Birey yine başka bir makro kapatılma unsuru olan yasakçı yasalardan ötürü, psikolojik olarak bu tür içerikleri hiçbir şekilde tüketmeme, interneti sadece eğlence için kullanma davranışını belli bir süre içinde edinebilir. Bu kavramı anlama noktasında Foucault'nun "panopticon" veya onun gelişmiş versiyonu olan süper-panopticon kavramları yine açıklayıcı olmaktadır, çünkü dijital ortamda, sürekli gözetim altında olduğunu düşünen bireylerin davranışlarını bu gözetene göre şekillendirmesinin olası bir psikolojik sonuç olduğu ileri sürülebilir.

Bununla beraber gözetlemeyi ve kişisel verilerinin depolanmasını umursamayacak kadar gözetlenme durumunu içselleştirme hali (Eser, 2020) bireylerde ortaya çlkabilir. Bu anlamda gözetlenme aşağıda yer verilen teşhircilik ve dikizleme, sahte kimlik yaratma, hedonizm ve sosyal medyanın kültür endüstrisi boyutu ile iç içedir. Kişi gözetlendiğini bile bile kişisel verilerinin depolanmasına izin veriyor ve görüşlerini paylaşıyorsa, bu durum içinde teşhircilik, sahte kimlik yaratma ya da kimliğini ya da görüşlerini tam olarak ortaya koymama (oto-sansür), hedonist saiklerle bu eylemlilik içinde bulunma ve görüşleri ve kişisel bilgilerinin kültür endüstrisinin bir parçası haline gelmesini içinde barındırır. $\mathrm{Bu}$ anlamda birey, büyük kapatılma içinde yaşayan, disiplinci toplumun oluşturmak istediği özne kalıbını doldurarak gerekli yerde oto-sansür uygulamasını bilen, interneti de aynı televizyonda olduğu gibi bir kültür endüstrisi aracı olarak kullanan, kendisi bu endüstrinin ürünlerini tükettiği gibi kendisinin de tüketilmesine izin veren ve internet özgürlügünün internet üzerinden aldığı hazza kıyasla değersiz olduğu bir durumdadır. Kiși tüm bunların birikimi ya da tüm bu unsurlarla ilișkili olarak internet üzerinde kendi adı ile var olsa da sahte bir kimlik yaratma arayışına giren bir varoluş içindedir.

\section{Teşhircilik ve Dikizleme}

İstihbarat sağlamaktan, denetime ve kapitalist pazarlama mantığına kadar farklı amaçlarla kullanılan gözetim, dijital ortamlar aracılığıyla gerçekleştirilen, günümüzde belki de elitlerin en ciddi hegemonya kurma aracı haline gelmiştir. İnsanların bıraktığı dijital izlerden faydalanan Cambridge Analytica gibi şirketler seçim sonuçlarını bile değiștirebilecek bir güce kavuşmuştur. Buradaki asıl soru insanların neden mahrem bilgilerini bile rahatça paylaşabildiğidir. Özel yaşam ve kamusal olan arasındaki ayrımın giderek kaybolduğunu ileri süren Markham ve Baym, kişilerin en özel şeyleri bile kimliği belirsiz kitlelerle paylaşma noktasında giderek daha istekli hale geldiklerini söylerler (2008).

Niedzviecki'nin (2009) deyimiyle bu durum "abartılı paylaşım" olarak yani "şahsi bilgileri ortaya sermek; kişinin bir blogda veya başka bir yayın organında özel hayatını teșhir etmesi; teşhire maruz kalan kişiden ısrarla onay beklemesi," şeklinde tanımlanabilirken içinde yaşadığımız çağ da "Dikizleme Kültürü Çă̆ı" olarak adlandırılabilir. Niedzviecki'nin 
söylediklerinden anladığımız kadarıyla kendini teşhir etmenin altında büyük bir dikizleme kültürü vardır:

"Dikizleme Kültürü" bir realiti şovdur; YouTube, Twitter, Flickr, MySpace ve Facebook'tur. Bloglar, chat odalarl, amatör porno siteleri, kendisini Jedi Şövalyesi sanan şişman bir çocuğun virüs gibi yayılan videosu, eski sevgilisiyle sevişen sarhoş arkadaşınızın cep telefonuyla çekilen fotoğrafları -elbette hemen çevrimiçi paylaşllır-ve sivil denetimdir. Dikizlemek Web 2.0'ın belkemiği, kurumsal ve siyasi veri tabanlarının lokomotifidir. Pornografi için derler ya: Görmeden bilemezsiniz! İște şimdi görüyorsunuz; her an, her gün, her yerde (2009, s. 8).

Çağımızda 'herkes' zamanında sadece ünlülerde olan şekilde bir kamusal hayat sürüyor ve ortaya saçtığımız her şey kaydediliyor ve bir ürün haline geliyoruz. $\mathrm{Bu}$ anlamda bakıldığında, bu derecede gözetime rağmen hala bir kendini teşhir etme ihtiyacına ya da Niedzviecki'nin deyimiyle dikizleme kültürüne, bireyin kendisinin bir meta haline dönüşme süreci olarak baktığımızda, bu süreci en iyi anlayabileceğimiz kavram kültür endüstrisidir.

\section{Üretilenin Yeniden Üretimi-Bir Kültür Endüstrisi Olarak İnternet}

Lister ve arkadaşları (2009, s. 76) internetin karşıt kamusal alan olarak görülmesi, enformasyonun ve iletişimin merkezi bir otoritenin elinde olmaması ve vatandaş gazeteciliği ile medyanın dördüncü güç fonksiyonunun dirilmesi gibi nedenlerle online iletişimin "pasif" ve inisiyatiften yoksun bireylerin üretimi olarak değil, aksine kimlik inşası ve değişim adına aktif bir süreç olarak görüldüğünü söylerler. Öte yandan Manovich (2009) bu duruma yönelik kültür endüstrisinin merkezinde bulunduğu bir soru sorar:

\footnotetext{
"Kullanıcı tarafından üretilen içeriğin önemli biryüzdesininya profesyoneleğlence sektöründekiler tarafindan üretilen şablon ya da gelenekleri takip ettiği ya da doğrudan profesyonel olarak üretilen içeriği (örneğin anime müzik videoları) tekrar kullandığı göz önüne alındığında, bu durum insanların kimliklerinin ve hayal güçlerinin günümüzde yirminci yüzyılı bile aşacak şekilde ticari medya tarafından aşırı derecede sömürüldüğü anlamına mı gelir? Başka bir deyişle: Yirminci yüzyıldaki ticari kültürün kitle tüketiminin erken dönem yirmi birinci yüzyıldaki kültürel objelerin kullanıcılar tarafından kitle tüketimi ile ikamesi ilerici bir gelişme midir? Ya da bu durum Adorno ve Horkheimer'ın kavramı olan "kültür endüstrisi"nin daha ileri bir düzeyini mi ortaya koyar? Aslında, yirminci yüzyıl bireyleri basit bir şekilde kültür endüstrisinin ürünlerini tüketiyorsa, yirmi birinci yüzyllın üreten tüketicileri ve profesyonel amatörleri tutkuyla onu taklit ediyorlar. Yani, şimdi onlar profesyoneller tarafindan üretilen şablonları takip ediyor ya da profesyonel içeriğe bağlı olan kendi kültürel ürünlerini ortaya koyuyorlar."
}

Manovich'in belirttiği gibi internette tüketiciler bir üretici konumuna gelse de kitle medyasında üretilen içerikleri tekrar üretme gibi bir problem ortadadır. Hille ve Bakker bu durumu 'kullanıcı katılımı'ndan ziyade 'kullanıcı dağıtımı' terimi kullanılmalı şeklinde savunurlar (2013). Öte yandan internette kullanıcıların özgün ve sıradan olmayan içerik üretme şansı tabii ki vardır. Ancak bununla beraber internetin de kendine öz bir ekonomi politiği olduğu düşünüldüğünde sadece internet için üretilen içeriklerin kitle medyasıyla aynı şekilde sıradan ve genele hitap eden bir forma büründüğü ileri sürülebilir. Bu noktanın bizi götüreceği yerlerden biri de internette tüketicilerin içerik sağlayıcılardan (bu bir Twitter fenomeni ya da Facebook kullanıcısı olabilir) hedonist taleplerini karşılama isteği ya da tam tersi internette içerik sağlayanların tüketicileri hedonizme yönlendirmeleridir.

\section{Hedonizm (Sanal Mutluluk)}

Hedonizm ya da hazcılık en üstün iyiliğin haz olduğunu ileri süren Aristippos'un öğretisidir. Her davranışın altında mutlu olma isteği yatar. Aristippos'un öğretisi günümüzde her türlü hazzı istemek ve her türlü acıdan kaçınmak olarak kullanılmaktadır (Hançerlioğlu, 
1982). Aristippos'un hedonizmi etik bir hedonizmdir, öte yandan psikolojik hedonizm de insan eylemlerinin benzer şekilde zevki muhafaza etme ve acıdan kaçınma arzusu tarafindan belirlendiği bir durumdur (Bunnin \& Yu, 2008).

Sosyal medyaya olan düşkünlügümüzü psikolojik ve hormonal bir açıdan ele alırsak, kişinin beynindeki sinir taşıyıcısı dopamin yolağını uyaran aktiveteler olan çikolata yeme ya da seks yapmaya benzer biçimde sosyal medyadan alınan her beğeni ve yorumlara da bağımlı olunabileceği ileri sürülmektedir (Huntsdale, 2015). Hazzın hoşa giden bir şeyin yarattığı duygu olduğunu hesaba katarsak, internet üzerinde bunun örnekleri olarak sosyal medya üzerindeki FarmVille vb. oyunları oynamak, internet üzerinden alışveriş yapmak (bağımlılık düzeyinde), başkalarını takip etmek (dikizlemek-stalking), cinsel dürtüleri tatmin amaçlı porno izlemek, aşağıdaki örneklerden biri olan sahte kimlik yaratmanın en önemli nedenleri arasında bulunan karşı cinsin ilgisini çekme çabası, sosyal medya fenomenlerinin komik bulunan sözlerini takip etmek ve stand-up şovmenlerinin viral hale gelmiş kısa versiyon videolarını ya da vine olarak da tabir edilen videoları izlemek sayılabilir. Yukarıdaki satırlara "haz almanın nesi yanlış" gibi bir eleștiri getirilebilir. Bu noktada önemli olan bu eylemlerin yapılmasından ziyade ne derecede yapıldığıdır. İnternete yönelik bu tip bir hazcı bakış takıntılara, korkulara ve bağımlılıklara neden olabilmektedir. Örneğin kişiler kompulsif satın alma ve aşırı mastürbasyon gibi rahatsızlıklar yaşayabilmekte, başkalarını dikizlemeyi takıntı haline getirebilmekte, gündemden uzakta kalmaktan ya da bir şeyleri kaçırmaktan (FOMO) korkabilmekte ve tüm bu saydığımız şeyler ya da bunların hemen hepsinden parçalar taşıyan bu yapıya bağımlı olabilmektedir.

Morozov (2011, s. 81), Steve Jobs ve Ashton Kutcher'ın Mao ya da Che'den çok daha fazla saygı gördügü günümüzde, otoriterliğin artık hedonizm ve tüketim karışımına duyulan tutku olduğunu söyler. Ona göre internetin otoriter rejim yönetimi, altında yaşayanlara o kadar fazla ucuz ve kolay şekilde ulaşılabilen eğlence ürünleri sağlamaktadır ki insanların politika ile ilgilenmelerini sağlamak oldukça zor bir hale dönüşmüştür. Hedonizm, cinsellik, like'lardan gelen ödüllendirilme duygusu ve eğlence temelli içerikleri takip etmeyi anlatır. Çoğu zaman gündelik hayatın yorucu temposundan bir kaçış için kısa bir rahatlama sağlar ya da geçici sanal mutluluk alemine bizi taşır. Bu kısımda ele alınan hedonizm ve yukarıda ele alınan dikizleme (başkalarını meraktan kaynaklı) temel içgüdülere dayanır. Bir sonraki başlıktaki seçici maruz kalma ve filtre balonlarının oluşturduğu kolektif nefret kültürü ise gruplara dâhil olma, diğerlerini etkileme, kendilerine zarar verebileceklerini düşündükleri kişilerden korunma ve bu amaçla örgütlenme, sıkı ilişkiler kurma ve öteki üzerinden kimliğin oluşumu gibi temel içgüdülere dayanmaktadır.

\section{Seçici Maruz Kalma ve Filtre Balonlarının Oluşturduğu Kolektif Nefret ve Komplo Teorisyenliği Kültürü}

Seçici maruz kalma kavramı, internet ya da sosyal medyanın ortaya çıkmasından önce ortaya çıkmıştır. En temelinde izleyicilerin kendi inanç ve düşüncelerinden farklı olan medya araçlarından kaçındıklarını ve kendilerine uyan medyalara yöneldiklerini anlatan bir kavramdır. Bu kavram aynı zamanda ortak referans noktalarına göndermede bulunur. Bunu Facebook'a uyarlarsak bir kullanıcı haber akışında görmek istediği sayfayı takip eder, onun içeriklerini beğenir ve yorumlar, yani etkileşime geçer ve algoritma da o tip içerikleri ona daha fazla gösterir. Buna ek olarak kullanıcı beğenmediği kişi ve grupları takipten çıkar ya da bir içeriği sakla fonksiyonunu kullanarak o tip içerikleri daha az görme şansını elde edebilir. Benzer şekilde algoritma bu tip içerikleri kullanıcıya göstermemeye başlayacaktır. Gerek klasik medyada gerekse yeni medyada bu durum 
kutuplaşmayı arttırıcı bir fonksiyona sahiptir. Himelboim ve arkadaşlarının bu konudaki çalışmasını inceleyen Aruguete ve Calvo (2018) bu konuda şöyle konuşur: "Sosyal medya içeriğine yönelik seçici maruz kalma bireylerin tercihleri ve inançları ile bilişsel olarak uygun olan içeriği aktif olarak aradıklarında ortaya çıkar." Bununla beraber sosyal ă sitelerinin diğer internet araçlarına kıyasla kazara maruz kalmaya yatkın olduğuna dair görüşler de vardır. Onlara göre paylaşarak, beğenerek, retweetleyerek, enformasyona kazara maruz kalma gerçekleşebilir. Çünkü bireyler sosyal ağ sitelerinde her zaman ne tüketeceklerini seçmezler (Casteltrione, 2014).

Sosyal ağ sitelerinde seçici maruz kalmanın ötesine geçtiğine dair görüşlerin çıkış kaynağı olan filtre balonu kavramı ise Google'ın kişiye özgü arama motoru sonucu ilkesiyle tartışılmaya başlanan bir kavramdır. Google'ın Alexa.com'a göre ırkçı sitelere ulaşım açısından tünel görevi gören siteler açısından başı çekmesi bu noktada önemli bir veridir (Klein, 2017). Sosyal ağlar da kişilerin bıraktığı izler, eş deyişle çıkartılan profilleri üzerinden onların siyasal eğilimleri üzerinden, kişiselleştirilmiş bir deneyimi kullanıcılarına sunar. Bir anlamda kişilerin seçici maruz kalma ile beğenileri daraltmasına ek olarak bu platformlar da onlara daha dar ve bir anlamda kendisi gibi olan insanlar ve deneyimler sunarak onları mutlu eder. Ticari mantık olarak (sitede kalma süresi ve etkileşimi arttırır ve aynı zamanda kişilerin profili çok net şekilde ortaya çıktığından hedefli reklamı kolaylaştırır) bu algoritma mantığı doğru gibi gelse de en temelinde kullanıcıları oldukları kişiden ya da bulundukları grup aidiyetinden bir adım bile ileri götürmeyen ve internete atfedilen e-müzakere gibi kavramlarla tamamen zit olan bir yapıdır. Pettman (2016, s. 80) bu kişileştirme durumunu örümceğin ağını tam olarak sineğe göre örmesi örneği ile dile getirir. Ona göre Silikon Vadisi de kendi 'yapışkan' önerilerini de kullanıcıların yoğun şekilde araştırılmış demografik ölçümlerine göre yapar. Filtre balonu kavramı özellikle Trump’ın seçim zaferi sonrası daha fazla konuşulmaya başlanmıştır. Seçimden sonra New York dergisi ‘Filtre Balonu Neden Trump’ın kazandığını ve Sizin Niye Bunu Öngöremediğinizi Açıklar (Baer, 2016)’ adlı başlığı atmış ve Nikki Usher Layser'dan şu alıntıyı yapmıştır:

"Biz her zaman anlaşabildiğimiz kişilerle görüşmek ve onayladığımız enformasyonu edinmek gayesiyle hareket ederiz ama normal hayatta tesadüf ihtimali de vardır. Bu ihtimali genellikle okumayı tercih ettiğiniz şeyin dışında bir şey keşfetmek olarak adlandırabiliriz. Şu anki büyük farklıllk ise hangi hikâyeleri göreceğini seçen 'otonom karar-verme'dir.' Haber merkezleri mükemmel olmamakla beraber, onlar en azından dünyada neler olduğuna dair birbiriyle çelișen görüşlere yer vererek bağlamsal bir farkındalık yaratabilirler. Eğer haber akışları vasıtasıyla sadece online enformasyon tüketirsek alışkanlıklarımızı değiștiremeyiz."

Seçici maruz kalma ile filtre balonunun farkı yukarıda belirtildiği gibi ilkinin kişinin bir TV kanalını açıp izlemesi gibi sosyal medyada da benzer şekilde kendisinin istediği kişiyi arkadaş olarak eklemesi, istediği gruba dahil olması ve sayfayı beğenmesidir. Ancak sosyal medyadaki filtre balonlarını yaratan algoritmik mantığın seçici maruz kalmayı da destekleyen yanları vardır. Aşırı sağ sayfalarla ilgilenen bir kişi bu tip paylaşımları beğendikçe benzer sayfalar ona daha çok gözükecek ve onun gibi düşünen kişilerin yaptıkları ona bildirim olarak düşecektir. Aynı zamanda bu kişinin sürekli etkileşime girdiği sayfalar diğerlerinin aksine daha fazla haber akışında belirecektir. Bu açıdan bakıldığında kişinin sosyal medya ortamında kendisini, kendine benzer insanlardan oluşan bir grubun üyesi olarak algılaması olağandır. Bu durumda sosyal medyanın bir gruba dâhil olma, toplumsal olarak kabul görme, diğerlerini etkileme, kendilerine zarar verebilecek insanlardan korunma ve öteki üzerinden kimliğin oluşumu gibi temel 
içgüdüler adına bir araç olduğu ileri sürülebilir. Bu grup bilinci ile gelen ötekileştirme ise nefret kültürünün yayılımına zemin hazırlamaktadır.

Seçici maruz kalma yaklaşımıyla örtüșen șekilde Curran'a (2012) göre dünya eşitsiz ve karşılıklı olarak dışlayıcıdır ve çatışan değerler ve çıkarlar tarafından bölünmüştür. Bu bölünmüşlük siber alana nüfuz etmektedir. Yeni medya ortamında gündelik söylemsel pratiklerde üretilen ve geleneksel medya metinlerinde dolaşıma sokulan homofobik, transfobik, yabancı düşmanı, ırkçı, etnik milliyetçi ve ayrımcı nefret söyleminin yeni medyanın özelliklerinden dolayı çok daha kolay bir biçimde yaygınlaşarak, sıradanlaşarak dolaşıma girmektedir (Binark, 2010). Allen (2014) minarelere ve camilere karşı olan Facebook gruplarını incelediği çalışmasında bazı grupların bilinçli olarak hakaretamiz olduğunu söyler. Ona göre gruplardaki hakaretamiz söylemleri ortaya koyanların çoğunun gerçek profillere sahip olması şaşırtıcıdır. Bu noktada eskiden kabul edilemez en azından kamusal söylemde kabul edilemez olan söylemlerin sosyal medya sayesinde meşrulaştığı tartışılabilir. Simon Simas'a göre bu tür söylemler için toplumsal izin durumu ya da daha açık bir ifadeyle daha önce düşünülemez olan için toplumsal bir onay duygusu oluşmuştur (Remnick, 2016).

İnternetin ve sosyal medyanın kontrolsüz ortamı ve kullanıcılarına sağladığı grup bilinciyle beraber histerik bir hal alabilmesi onun irkçılık ve nefret söylemleri kadar komplo teorilerinin de rahatça dolaşabildiği bir ortama dönüşmesini sağlar. Sosyal medyada kișilerin bir grubun üyesi gibi davranma ihtiyacı ve filtre balonlarından ötürü sürekli aynı tip enformasyonlara maruz kalıp onları tekrar üretmeleri sosyal medya şirketlerinin kâr mantığıyla sürekli kişinin hoşuna gidecek şeyleri onlara gösteren ve kendi gibi olanlarla beraber olma imkânı veren algoritmalardan kaynaklı bir kapatılma türüdür.

\section{Sanal/Sahte Kimlik Yaratma}

Yukarıda belirtildiği gibi sahte ya da sanal kimlik yaratma hedonist amaçlara hizmet eden bir kapatılma türüdür ve bu durum internetin gerçek olmayan bir şekilde kullanıldığından onun eleştirel bir ortam olarak kullanılma, karşı bir kamusal alana dönüşme ihtimalini sıfırlar. Bu sahte kimlik, anonim kimlik bir yana nonim bile olsa sosyal medyada kendi kimliğimizle var oluyormuşuz gibi gözüken bir pozisyonda aslında gerçek gibi görünen kimliğimizin sahte olması ile alakalıdır. Eş deyişle kişiler sosyal medyada kendi kimliklerini oynuyormuşçasına bir performans sergilemektedirler. Sosyal mecralar bireyleri bir anlamda sürekli aslında hayatında olmayan insanlarla iletişim kurma gereksiniminde bırakır. Bu durum belli oranda gerçeklikten kopma ve daha rahat yalan söyleyebilme imkânı vermekle beraber kamusal alana içerik ürettiğinden hedef kitlesine göre kendini şekillendirme (sosyal medya aktivistliği ya da slacktivizm ve sosyal medya dindarlığı) ve zengin, mutlu gözükmek adına bazı özelliklerini parlatma ihtiyaçlarını doğurur. Sanallaşma bir anlamda gerçekliğin ortadan kalktığı yeni bir uzamı gündeme getirir. Varlığın fiziksel olarak var olmadan bu uzamda olması bir paradigma değişimi olarak tanımlanabilir.

Bunlarla beraber kişinin kendisinin medya olmasının bir rekabet boyutu vardır. Kitle medyasında reytinglerle ölçülen bu değerlendirme sosyal mecralarda, yapılan paylaşımın beğenilme ya da retweet edilme sayısı ya da arkadaş veya takipçi sayısı ile ölçülür. Kapitalist maksimum kâr mantığına benzer maksimum ilgi, takip edilme ve beğenilme mantığının bireylerin her birinin önemli bir yaşam motivasyonu haline gelmesi onların 
sahte bir kimliğe bürünüp sahte ihtiyaçlar ile motive olmalarını sağlarken özgürleștirici bir doğası olan internet adına en ciddi kapatılmalardan birini yaratmaktadır.

\section{Tartışma ve Sonuç}

Bu makalede ele alınan makro ve mikro kapatılma konuları internete yönelik ilk çıktığı günlerdeki olumlu bakış açısından çok farklı bir noktada olduğumuzu bize gösterir. $\mathrm{Bu}$ yapısal değişimlerden biri de internetteki özgün içerik ve kullanıcıların kendi görüşlerini ifade edebilme imkânlarının artmasına rağmen bu mecranın giderek kitle iletişim araçlarına benzeyerek bir kitle endüstrisi halini almasıdır. Kitle medyasında pompalandığı şekilde tüketmenin insanı özgürleștireceği (kot pantolon giymek, Starbucks'tan kahve içmek ya da pahalı arabalara binmek Rusya'yı ve Çin'i ne özgürleştirdi ne de demokratikleştirdi) ya da belli markaları tüketenlerin daha değerli olarak atfedildiği kapitalist mantığın, interneti de giderek ele geçirdiği bir dönemi yaşıyoruz.

Her ne kadar Assange ve arkadaşları bu kavramsallaştırmayı bu çalışmadaki gibi yapmasalar da makro kapatılmaya karşı şifreleme olarak bilinen yöntemin başarılı olacağını savunmaktalar ve John Gilmore’un "İnternet sansürü bir hasar gibi algılar ve devredışı bırakır," sözünü hatırlatmaktalar (2013). Makro kapatılma internet özgürlüğü için oldukça tehlikeli bir eylemliliktir. Ancak daha önce Wikileaks'e Amerikan hükümetinin yapmaya çalıştığı makro kapatılmada gördüğümüz gibi bu kapatılma internetin kendine has özelliklerinden dolayı belli oranda aşılabilen bir kapatılmadır. İnternet özgürlüğü için asıl tehlike arz eden kapatılma ise bu tür makro kapatılmaları umursamayacak hale gelmiş bir internet kullanıcısı ve kültür endüstrisi haline dönüşmüş bir internet ortamıdır, eş deyişle mikro kapatılmadır. Bir kültür endüstrisi olarak internette yaratılan ürünleri meta olarak tüketme ve kullanıcı değil tüketici olmanın internet açısından tehlikesi kendisi de bir medyaya dönüşebilen bireylerin hem kendilerinin hem de ürettiği içeriklerin de bir metaya dönüşmesidir. Gözetimden korkan ona göre şekillenen, sürekli teşhircilik yapan ve başkalarını dikizleyen, hedonist çıkarları adına sahte bir kimlik yaratmaktan çekinmeyen birey tipinin disiplinci iktidarın istediği özne konumunu tam olarak benimseyeceği söylenebilir.

Postman'ın (1985) televizyona yönelik meta-ortam bakış açısı günümüzde internete karşılık gelmektedir. Bunun nedeni bir şeyi bilme yolumuzun artık internet üzerinden geçmesidir. Bu açıdan bu teknoloji ve bağlı cihazların insanları değiştirme kapasitesi toplumları yönlendirmek isteyenler için bulunmaz bir nimettir.

Cebri kontrol ve konsensüs kontrolünü ele aldıkları 1984 ve Cesur Yeni Dünya kitaplarında Orwell kitapların yasaklanacak olmasından, Huxley onları okuyacak kimsenin olmamasından, Orwell bilgiden yoksun edecek kişilerden, Huxley bize gereken fazlasını verip pasif ve bencil hale düşürülmemizden ve son olarak Orwell doğrunun saklanmasından, Huxley eğlence sayesinde bilginin ilgisizlik dehlizinde boğulmamızdan korkuyordu (Postman, 1985) - (McMillen, 2009). İnternette, mikro kapatılmanın makro kapatılmaya göre çok daha etkili olduğu düşünüldüğünde yeni teknolojilerden habersiz yazdıkları bu distopik eserlerinde Huxley toplumun geleceğini tahmin etme açısından Orwell'e göre daha başarılı duruyor.

\section{Notlar}

1 Buradaki sava karşıt olarak Foucault ekonominin temel belirleyen olduğu ve belirlenen bir üst yapı olduğuna dair Marksist düşünceleri reddeder... Bunun yerine Althusser gibi kompleks ve çoklu nedensellikleri ve toplumsal yapıya mündemiç bir belirlenimciliği içeren bir model kullanır... Bu modelinde pratik kavramını kullanır ve pratiklerin nasıl uygulandığı ve 
insanların çevresine göre nasıl bir eylemlilik içinde olduklarını anlayabilmek adına strateji kavramını ortaya koyar (Olsen, 2004).

2 https://innovation.defense.gov/About1/

\section{Kaynakça}

Alford, C. F. (2000). What would it matter if everything foucault said about prison were wrong?" discipline and punish" after twenty years. Theory and society, 29(1),, 125146.

Allen, C. (2014). Anti-social networking: findings from a pilot study on opposing Dudley mosque using Facebook groups as both site and method for research. Sage Open, 4(1).

Aruguete, N., \& Calvo, E. (2018). Time to\# protest: Selective exposure, cascading activation, and framing in social media. Journal of communication 68.3, 480-502.

Assange, J. (2014). When Google met WikiLeaks. OR Books.

Assange, J., Appelbaum, J., Müller-Maguhn, A., \& Zimmermann, J. (2013). Şifrepunk: Özgürlük ve internetin geleceği üzerine bir tartışma. Metis.

Baer, D. (2016, Kasım 09). The 'Filter Bubble' explains why Trump won and you didn't see it coming. https://www.thecut.com/: https://www.thecut.com/2016/11/howfacebook-and-the-filter-bubble-pushed-trump-to-victory.html adresinden alındı

Binark, M. (2010). Nefret söyleminin yeni medya ortamında dolaşıma girmesi ve türetilmesi. T. Çomu içinde, Yeni Medyada Nefret Söylemi (s. 11-53).

Buchanan, I. (2007). Deleuze and the internet. Australian Humanities Review, 1-19.

Bunnin, N., \& Yu, J. (2008). The Blackwell Dictionary of Western Philosophy. John Wiley \& Sons.

Carr, N. (2020). The shallows: What the internet is doing to our brains. . New York: WW Norton \& Company.

Casteltrione, I. (2014). Facebook and political information in Italy and the UK: An Antidote against Political Fragmentation and Polarisation? Online Journal of Communication and Media Technologies.

Curran , J. (2012, Mart 04). Why has the internet changed so little? Eylül 22, 2020 tarihinde https://www.opendemocracy.net/: https://www.opendemocracy.net/ en/why-has-internet-changed-so-little/ adresinden alındı

Deacon, R. (2006). From confinement to attachment: Michel Foucault on the rise of the school. European Legacy, 11(2), , 121-138.

Ertem, C., \& Uçkan, Ö. (2011). Wikileaks yeni dünya düzenine hoşgeldiniz N. Etkileşim.

Eser, E. (2020, 09 18). 'Kişisel veriler umurumda değil'. https://www.hurriyet. com.tr: https://www.hurriyet.com.tr/ekonomi/kisisel-veriler-umurumdadegil-41614403 adresinden alındı

Foucault, M. (1980). Power/knowledge: Selected interviews and other writings. Vintage.

Foucault, M. (1988). Madness and civilization: A history of insanity in the age of reason. . Vintage. 
Foucault, M. (2011). Büyük kapatılma. (I. Ergüden, \& F. Keskin, Çev.) İstanbul: Ayrıntı Yayınları.

Hançerlioğlu, O. (1982). Felsefe sözlüğü . Remzi Kitabevi.

Hassan, R. (2019). Uncontained: Digital disconnection and the experience of time.

Hille , S., \& Bakker, P. (2013). I like news. Searching for the 'Holy Grail'of social media: The use of Facebook by Dutch news media and their audiences. European Journal of Communication, 28(6),, 663-680.

Huntsdale, J. (2015, Ocak 23). Unliking Facebook - the social media addiction that has you by the throat. https://www.abc.net.au/: https://www.abc.net.au/local/ stories/2015/01/23/4167400.htm adresinden alındı

Kalelioğlu, E. (2020, Haziran). Google, Android 11'de APK'dan uygulama yüklemeyi zorlaştıracak. webtekno: https://www.webtekno.com/android-11-apkdanuygulama-yukleme-zorlastiracak-h94161.html adresinden alındı

Keskin, F. (2011). Sunuş: Büyük kapatılma. Istanbul: Ayrıntı Yayınları.

King, J. (Yöneten). (2006). Steal this film [Sinema Filmi].

Klein, A. (2017). Fanaticism, racism, and rage online; Corrupting the digital sphere. Springer.

Lakshmanan, R. (2019, Aralık). Russia to pre-install its own apps on all phones, PCs, and TVs sold in the country. https://thenextweb.com/: https://thenextweb.com/ security/2019/11/22/russia-to-pre-install-its-own-apps-on-all-phones-pcs-andtvs-sold-in-the-country/ adresinden alındı

Lister, M., Dovey, J., Giddings, S., Kelly, K., \& Grant, I. (2009). New media: A critical introduction. Taylor \& Francis.

Manovich, L. (2009). The practice of everyday (media) life: From mass consumption to mass cultural production? Critical Inquiry, 35(2), 319-331.

Markham, A. N., \& Baym, N. K. (2008). Internet inquiry: Conversations about method. Sage Publications.

McMillen, S. (2009, Mayıs 01). Amusing ourselves to death by Stuart McMillen. Eylül 22, 2020 tarihinde https://myowncrapplace.files.wordpress.com/: https:// myowncrapplace.files.wordpress.com/2011/07/2009-05-amusing-ourselves-todeath.png adresinden alındı

Morozov, E. (2011). The net delusion: The dark side of internet freedom. New York: Public Affairs.

Nelson, S. (2018, 9 5). Facebook, Twitter execs defend non-censorship of WikiLeaks. 2020 tarihinde https://www.washingtonexaminer.com/: https://www. washingtonexaminer.com/news/white-house/facebook-twitter-execs-defendnon-censorship-of-wikileaks adresinden alındı

Niedzviecki, H. (2009). The peep diaries: How we're learning to love watching ourselves and our neighbors. City Lights Publishers.

Olsen, M. (2004). Foucault and Marxism: rewriting the theory of historical materialism. Policy Futures in Education, 2(3-4), 454-482. 
Paltemaa, L., Vuori, J., Mattlin, M., \& Katajisto, J. (2020). Meta-information censorship and the creation of the Chinanet bubble. Information, Communication \& Society, 1-17.

Pettman, D. (2016). Infinite distraction. John Wiley \& Sons.

Porter, R. (1990). Foucault's great confinement. History of the Human Sciences, 47-54.

Postman, N. (1985). Amusing ourselves to death: Public discourse in the age of television. New York: Viking.

Remnick, D. (2016, Kasım 16). obama reckons with a trump presidency. Eylül 22, 2020 tarihinde https://www.newyorker.com/: https://www.newyorker.com/ magazine/2016/11/28/obama-reckons-with-a-trump-presidency adresinden alınd

Shervin, E. (2019, 02 14). Rusya küresel internet ağıyla bağlantısını kesmeye hazırlanıyor. https://www.dw.com/tr: https://www.dw.com/tr/rusya-k\%C3\%BCreselinternet-a\%C4\%9F\%C4\%B1yla-ba\%C4\%9Flant\%C4\%B1s\%C4\%B1n\%C4\%B1kesmeye-haz\%C4\%B1rlan\%C4\%B1yor/a-47511083 adresinden alındı

Warf, B. (2011). Warf, Barney. “Geographies of global Internet censorship. GeoJournal 76.1, 1-23. 


\title{
Macro and Micro Confinement as a Pessimistic Perspective towards Internet
}

\author{
Ahmet Faruk Çeçen (Asst. Prof. Dr.)
}

\section{Extended Abstract}

An optimist perspective towards the internet which stems from its decentralized technical structure has recently given place to discussions, centering on oppression and freedom, an optimist vs. pessimist debate. This study takes sides with the pessimistic approach and aims to elaborate that by taking advantage of the Foucauldian perspective. According to Foucault, a specific time (exactly 1656) in European history has witnessed a noticeable change that occurred thanks to the foundation of Hôpital Général. The institution that seemingly sounds like a medical one wasn't meant to be built and run for curing patients. According to Foucault, it is rather a sort of semi-judicial structure, an administrative entity which, along with the already constituted powers, and outside of the courts, decides, judges, and executes...Hôpital Général is a strange power that the King establishes between the police and the courts, at the limits of the law: the third order of repression (1988). After a while, all across Europe beggars, petty criminals, layabouts, prostitutes, and even sick and the old, the lame, and lunatics were confined. Such problem people, though different from normal citizens, were identical amongst themselves. Their common denominator was idleness. The mad did not work; those who did not work were the essence of unreason (Porter, 1990, p. 47). So, the whole point of this confinement would seem to discipline the problem people but actually, it was the first stage in the early modern history of discipline 1600-1750 (Deacon, 2006). The discipline that turns out to be common, making the great confinement a general phenomenon which is not only for the so-called lunatics but also for the whole society and each individual and their soul. So, power has transformed into something else in the West which is not stable anymore and a status named capillary power reaches into the very grain of individuals, touches their bodies, and inserts itself into their actions and attitudes, their discourses, learning processes, and everyday lives (Foucault, 1980), in other words, it reaches into individuals so deeply that it makes them who they are (Alford, 2000). Taking advantage of Foucault's confinement concept and applying it to the internet, this work argues restriction of internet freedom could be happening in macro and micro levels, emphasizing direct and indirect confinements respectively.

As explained above, the internet can't be stopped completely. Although there are internationally agreed norms to fight against cybercrimes such as child pornography, online human trafficking, and selling illegal drugs and other goods online that are overseen by international bodies like Interpol and local governmental bodies, the abovementioned acts can still be carried out. According to Buchanan (2007), there has been an unquestioned presupposition that the internet is an agent of freedom. Accordingly, the emergence of freedom of information movements like Wikileaks has been shown as the representative of this idea. Wikileaks has been censored directly, financially and its members have been harassed and detained. Assange et al. (2013) believe that "people in power see internet like an illness that affects their ability to define reality," so it is natural to try to censor "the illness" the way it had been done by elites in 1656 by setting up the institution named Hôpital Général to herald the age of Great Confinement. To legitimate, the confinement of the so-called 'problem people' the conditions of the confinement 
should be generally accepted. As a direct intervention on a macro level, confining "the problem people" in the $17^{\text {th }}$ century by labeling them useless is similar to censor Wikileaks by categorizing the members of Wikileaks as terrorists, marginal, and thief in the $20^{\text {th }}$ century. Looking at the evolution of Foucault's concept of confinement, it can be seen that it has followed a course from a specific typology to the whole society from physical confinement to the psychological one. Similar to that, it is argued in this study that censoring the internet (macro-level) can both jeopardize internet freedom directly and help to create an environment where individuals only care about enjoying the time they spend on the internet. The environment created and tools provided by these macro structures and the individuals per se have been contributing a specific subject type who is unwilling to demand freedom (micro-level). Contrary to macro confinement, micro confinement is carried out by the individuals to themselves or they would have acted differently, like figuring out the way to get out of the system created by macro structures. Therefore, it should be emphasized that internet freedom must be discussed not in terms of governmental repression but individuals' actions.

Keywords: Disciplinary Power, Great Confinement, Internet Freedom, Macro Confinement, Micro Confinement.

Bu makale intihal tespit yazılımlarıyla taranmıştı. Intihal tespit edilmemiştir.

This article has been scanned by plagiarism detection softwares. No plagiarism detected.

Bu çalışmada "Yükseköğretim Kurumları Bilimsel Araştırma ve Yayın Etiği Yönergesi" kapsamında uyulması belirtilen kurallara uyulmuştur.

In this study, the rules stated in the "Higher Education Institutions Scientific Research and Publication Ethics Directive" were followed. 